\title{
PENGARUH BAKTERI Pseudomonas fluorescens dan Paenibacillus polymixa TERHADAP INTENSITAS PENYAKIT HAWAR UPIH SERTA PERTUMBUHAN TANAMAN JAGUNG HIBRIDA P27
}

\author{
Andi Irwansyah ${ }^{1}$, Suskandini Ratih Dirmawati², Muhammad Nurdin², \& Cipta Ginting ${ }^{2}$ \\ 1. Mahasiswa Agroteknologi, Fakultas Pertanian Universitas Lampung \\ 2. Dosen Jurusan Agroteknologi, Fakultas Pertanian Universitas Lampung \\ Jln. Prof. Dr. Ir. Soemantri Brodjonegoro, No, 1 Bandar Lampung 35145 \\ E-mail : andiirwansyah73@gmail.com
}

\begin{abstract}
ABSTRAK
Jagung merupakan tanaman pangan penting di Indonesia, salah satu kendala dalam budidaya tanaman jagung adalah serangan penyakit hawar upih yang disebabkan oleh cendawan Rhizoctonia solani. Penelitian ini bertujuan untuk mengetahui pengaruh bakteri Pseudomonas fluorescens dan Paenibacillus polymixa terhadap intensitas penyakit hawar upih dan pengaruh terhadap pertumbuhan tanaman jagung. Penelitian ini dilakukan pada bulan Juli 2017 sampai bulan Agustus 2017, di Desa Rantau Minyak, Kecamatan Candipuro, Kabupaten lampung selatan. Penelitian disusun dalam rancangan acak lengkap (RAL) terdiri atas lima perlakuan dan empat ulangan. Perlakuan terdiriatas (1) P0 kontrol berupa tanaman jagung yang tidak diberi perlakuan fungisida serta bakteri $P$. polymixa dan bakteri $P$. fluorescens (2) P1 perendaman benih pada suspensi bakteri $P$. polymixa pada benih jagung selama 12 jam (3) P2 perendaman benih pada suspensi bakteri $P$. fluorescens pada benih jagung, selama 12 jam (4) P3 perendaman benih jagung pada suspensi bakteri $P$. polymixa dan bakteri $P$. fluorescens, selama 12 jam dan, (5) P4 perendaman benih jagung pada fungisida propineb $70 \%$ selama 12 jam. Data yang diperoleh kemudian dianalisis dengan menggunakan sidik ragam kemudian dilanjutkan dengan uji Beda Nyata Terkecil (BNT) pada taraf nyata 5\%. Hasil dari penelitian ini menunjukan bahwa penggunaan bakteri Pseudomonas fluorescens dan Paenibacillus polymixa tunggal dan campuran tidak berpengaruh terhadap penurunan intensita spenyakit hawar upih. Perlakuan menggunakan bakteri P. fluorescens dan P. polymixa secara tunggal memberikan pengaruh terhadap tinggi tanaman dan hasil produksi jika dibandingkan dengan perlakuan control dan perlakuan menggunakan fungisida Propineb 70\%.
\end{abstract}

Kata Kunci : Bakteri, Hawar upih, Jagung hibrida, Paenibacillus polymixa, Pseudomonas fluorescens, Rhizoctonia solani

\section{PENDAHULUAN}

Jagung (Zea mays L.) merupakan salah satu tanaman pangan penting, yang menjadi sumber karbohidrat kedua setelah padi. Kebutuhan pangan dari hasil tanaman jagung terus meningkat setiap tahun, oleh karena itu saat ini pemerintah sedang melakukan upaya khusus di seluruh daerah. Propinsi Lampung merupakan salah satu sentral produksi jagung. Di Lampung, jagung ditanam di hampir semua kabupaten yaitu kabupaten Lampung Selatan, Lampung Timur dan 
Lampung Tengah. Produksi jagung Lampung pada tahun 2012 sebesar 1,75 juta ton dan mengalami penurunan sebanyak 67 ribu ton dibandingkan produksi pada tahun 2011 (BPS Lampung, 2012).

Salah satu kendala dalam usaha peningkatan produksi jagung adalah gangguan penyakit tanaman yang menyebabkan produktivitas rendah. Penyakit pada tanaman jagung diantaranya adalah penyakit hawar upih daun yang disebabkan oleh cendawan Rhizoctonia solani Kuhn (Nuryanto, 2010). Cendawan Rhizoctonia solani merupakan patogen tular tanah (soil borne pathogen) yang bertahan dalam tanah dalam bentuk sklerotium dan miselium, terutama pada tanah-tanah yang banyak mengandung bahan organik dan mempunyai kisaran inang yang luas (Soenartiningsih, 2015).

Selama ini pengendalian penyakit hawar upih belum dilakukan oleh petani. Jika dilakukan pengendalian pada umumnya dengan cara penyemprotan kimiawi sehingga mempunyai dampak negatif. Beberapa dampak negatif diantaranya adalah matinya organisme non-target yang menyebabkan berkurangnya keanekaragaman hayati dan terganggunya ekosistem. Dampak lain yang dapat terjadi adalah resistensi pada target, dan bahaya keracunan bagi operator, dan pencemaran lingkungan.

Oleh karena itu diperlukan alternatif pengendalian lainnya yaitu dengan penggunaan agensia hayati. Penggunaan agensia hayati berpotensi tinggi menghambat serangan patogen, mampu beradaptasi dan berkolonisasi pada perakaran tanaman. Bakteri yang dapat dijadikan sebagai agensia hayati diantaranya adalah Pseudomonas fluorescens dan Paenibacillus polymixa. Kedua bakteri ini juga merupakan bakteri yang dapat berfungsi sebagai PGPR (Plant Growth Promoting Rhizobacter), bersifat antagonis terhadap patogen tular tanah karena menghasilkan zat antibiotik, serta dapat menginduksi ketahanan sistemik tanaman. Sebagai contohnya yaitu yang telah dilakukan oleh Nawangsih (2006) yang menggunakan bakteri antagonis $P$. fluorescens dalam menghambat perkembangan $R$. solanacearum pada tomat. Haggag (2007) melaporkan bahwa bakteri P. polymixa, dapat menginduksi ketahanan kacang tanah terhadap penyebab penyakit busuk mahkota (Apergillus niger). Uraian diatas menunjukkan bahwa $P$. fluorescens dan P. polymixa memiliki kemampuan untuk menekan pertumbuhan cendawan patogen, sehingga dimungkinkan bakteri ini dapat mengurangi intensitas penyakit pada tanaman jagung. Oleh karena itu dianggap perlu untuk melakukan penelitian ini.

\section{METODE PENELITIAN}

Penelitian ini dilaksanakan di Desa Rantau Minyak, Kecamatan Candipuro, Kabupaten Lampung Selatan, pada bulan Juni 2017 sampai bulan September 2017. Alat yang digunakan dalam penelitian ini adalah cawan petri, pembakar bunsen, kaca preparat dan penutupnya, mikroskop majemuk, jarum ose, autoklaf, plastik tahan panas, alumunium foil, cangkul, penggaris dan alat tulis. Bahan-bahan yang digunakan dalam penelitian ini adalah benih jagung P27, suspensi bakteri $P$. polymixa dan isolat $P$. fluorescens, fungisida berbahan aktif propineb $70 \%$ dan akuades steril. 


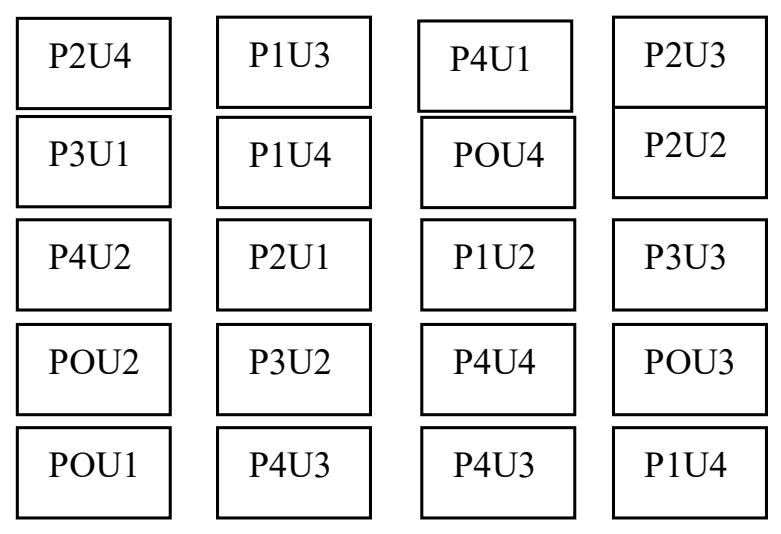

Gambar 1. Layout penelitian

Keterangan :

P0 = Kontrol berupa tanaman jagung yang tidak diberi perlakuan bakteri $P$. polymixa dan $P$. fluorescens atau fungisida propineb $70 \%$

P1 = Perendaman benih pada suspensi bakteri $P$. polymixa selama 12 jam

P2 = Perendaman benih pada suspensi bakteri P. fluorescens selama 12 jam

P3 $=$ Perendaman benih pada suspensi $P$. polymixa dan $P$. fluorescens selama 12 jam

P4 = Propineb $70 \%$ selama 12 jam

U1 =Ulangan 1

U2 =Ulangan 2

U3 =Ulangan 3

U4 =Ulangan 4

Penelitian disusun dalam rancangan acak lengkap (RAL) terdiri atas lima perlakuan dan empat ulangan. Perlakuan terdiri atas (1) P0 kontrol berupa tanaman jagung yang tidak diberi perlakuan fungisida serta bakteri P. polymixa dan bakteri P. fluorescens (2) P1 perendaman benih pada suspensi bakteri $P$. polymixa pada benih jagung selama 12 jam (3) P2 perendaman benih pada suspensi bakteri P.fluorescens pada benih jagung, selama 12 jam (4) P3 perendaman benih jagung pada suspensi bakteri $P$. polymixa dan bakteri P.fluorescens, selama 12 jam dan, (5) P4 perendaman benih jagung pada fungisida propineb 70 $\%$ selama 12 jam.

Data dianalisis dengan sidik ragam kemudian dilanjutkan dengan uji Beda Nyata Terkecil (BNT) pada tarifnyata $5 \%$.

\section{Suspensi $P$. polymixa dan $P$. fluorescens} dibuat dengan cara mensuspensikan 1 cawan biakan $P$. polymixa dan $P$. fluorescens dengan air steril sebanyak $100 \mathrm{ml}$. Suspensi digunakan untuk merendam benih. Benih jagung P27direndam dalam suspensi $P$. polymixa dan P.fluorescens selama 12 jam. Inokulasi hawar upih daun dilakukan dengan cara meletakkan tanaman sakit bergejala hawar upih daun di dalam polibag di antara tanaman tanaman jagung sehat.

Pengamatan dilakukan pada keparahan penyakit tanaman jagung dan masa inkubasi. Keparahan penyakit dihitung dengan rumus yang dikemukakan oleh James (1971):

$$
\mathrm{KP}=\frac{\sum(z \cdot n)}{\mathrm{Z} \cdot \mathrm{N}} \times 100 \%
$$

Keterangan :

KP : keparahan penyakit

Z : jumlah jaringan terserang pada setiap kategori (skor)

n : kategori (skor) serangan

$\mathrm{Z} \quad$ : kategori serangan tertinggi

$\mathrm{N}$ : total dari jumlah jaringan yang diamati 


\section{HASIL DAN PEMBAHASAN}

\section{A. Hasil}

\section{Intensitas Penyakit Hawar Upih}

Penyakit hawar upih jagung mempunyai gejala awal bercak kuning kemerahan, bercak kemudian menyebar pada permukaan upih dan pada akhirnya bagian yang bergejala tersebut mengering (Gambar 2a). Penyakit hawar upih disebabkan oleh Rhizoctonia solani yang mampu hidup di dalam tanah dalam bentuk sklerotium dan miselium (Gambar 2b).

Perkembangan intensitas penyakit hawar upih pada masing-masing perlakuan setiap minggunya terus meningkat, namun intensitas penyakit hawar upih tidak berbeda pada semua perlakuan. Pada minggu ke- 8 intensitas penyakit hawar upih jagung pada perlakuan Kontrol $39.42 \%$, P. polymixa $26.47 \%$, perlakuan $P$. fluorescens, perlakuan campuran P. polymixa dan $P$. fluorescens dan Fungisida adalah 32.85\%, 35.97 \% dan 38.9\% (Tabel1). Hasil penelitian menunjukan bahwa perlakuan P.polymixa dan P.fluorescens tidak menurunkan intensitas penyakit hawar upih.

\section{Tinggi Tanaman}

Data hasil pengamatan menunjukan bahwa perlakuan berpengaruh terhadap tinggi tanaman. Pengamatan pada minggu ke-5 sampai dengan minggu ke-8 menunjukan bahwa perlakuan $P$. polymixa dan P.fluorescens memiliki tinggi tanaman yang paling tinggi. Perlakuan $P$. polymixa dan $P$. fluorescens pada minggu ke-5 sampai minggu ke-6 menunjukan hasil yang tidak berbeda nyata antara dua perlakuan namun berbeda nyata dengan perlakuan Kontrol, Perlakuan Campuran P. polymixa dan P. fluorescens dan Fungisida.

Data perlakuan tidak nyata berdasarkan perhitungan statistik 


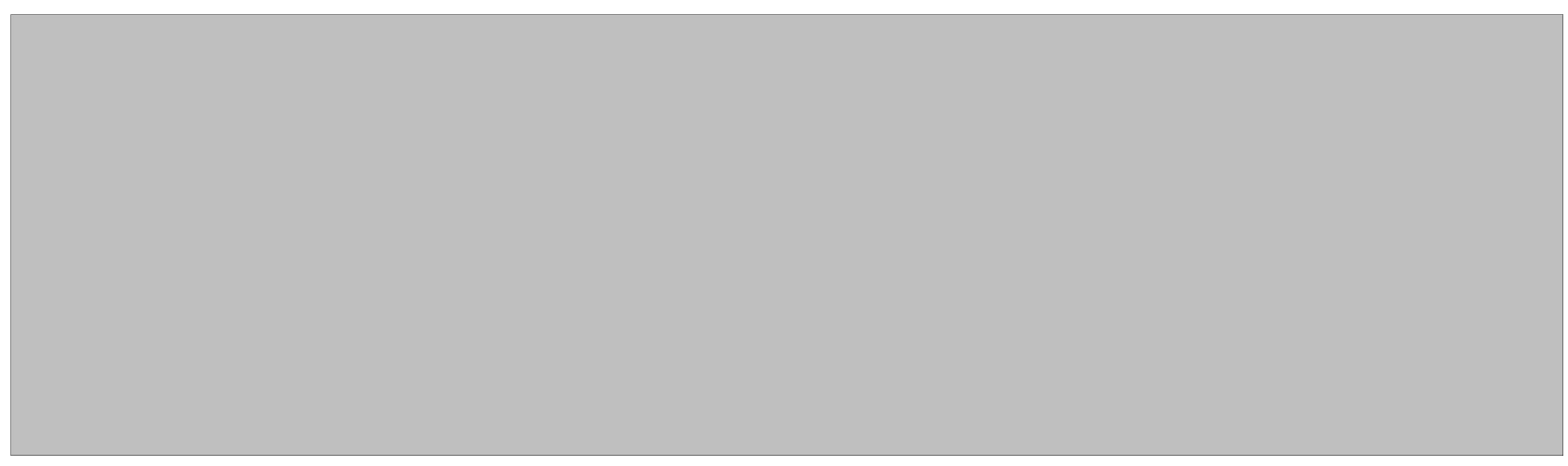

Angka yang diikuti oleh huruf yang sama dalam satu kolom tidak berbeda nyata pada uji lanjut BNT 5\%.

Pada minggu ke-7 perlakuan $P$. polymixa, $P$. fluorescens dan Perlakuan campuran P. fluorescens dan P. polymixa tidak berbeda nyata, namun ketiganya berbeda nyata dengan perlakuan Kontrol dan Fungisida. Pengamatan tinggi tanaman pada minggu ke8 menunjukan bahwa perlakuan $P$. polymixa dan $P$. fluorescens meningkatkan tinggi tanaman namun kedua perlakuan tersebut berbeda nyata dengan perlakuan Kontrol, Perlakuan campuran $P$. fluorescens dan $P$. polymixa dan Fungisida.

\section{Hasil Produksi}

Data hasil produksi tanaman jagung menunjukkan bahwa perlakuan $P$. polymixa dan $P$. fluorescens secara tunggal berpengaruh nyata terhadap bobot kering tongkol jagung yaitu sebesar 166.2 gram dan 130.8 gram, kedua perlakuan tersebut berbeda nyata dengan perlakuan Kontrol, Perlakuan campuran P. fluorescens dan P. polymixa dan fungisida, dengan hasil 92.7 gram, 104.3 gram dan 98.9 gram.

\section{B. Pembahasan}

Data hasil penelitian menunjukkan bahwa perlakuan menggunakan bakteri $P$. fluorescens dan $P$. polymixa tunggal dan campuran tidak berpengaruh nyata terhadap intensitas penyakit hawar upih. Beberapa sumber dari hasil penelitian menyatakan bahwa bakteri P.fluorescens dapat menginduksi sistem ketahanan tanaman terhadap serangan patogen dengan cara menghasilkan siderofor berupa asam salisilat, pioverdin atau piokelin, yang berfungsi sebagai sinyal transduksi ISR (Induced Systemic Resistance) (De Meyer \& Hofte 1997). P. polymixa merupakan bakteri tanah yang dapat menjadi bakteri antagonis

Angka yang diikuti oleh huruf yang sama dalam satu kolom tidak berbeda nyata pada uji lanjut BNT 5\%. 
dengan cara menghambat aktivitas patogen atau memicu ketahanan sitemik, memiliki kemampuan untuk menghasilkan asam glukosa, mannitol, arabinose dan xylose dan, dapat tumbuh pada pH 5.7 (Sheela \& Usharani. 2013). Dalam penelitian ini, penyebab bakteri P. fluorescens dan P. polymixa tidak berpengaruh terhadap penurunan intensita penyakit hawar upih adalah dosis yang digunakan tidak efektif, karena pada penelitian sebelumnya dengan menggunakan formulasi bakteri dari sumber yang sama, bakteri P.fluorescens dan P. polymixa dapat menekan keparahan penyakit karat daun yang disebabkan oleh Puccinia sorghi dan penyakit hawar daun yang disebabkan oleh Helminthosporium turcicum (Prasetyo. 2017).

Data hasil penelitian menunjukan bahwa penggunaan bakteri $P$. fluorescens dan $P$. polymixa secara tunggal memberikan pengaruh terhadap tinggi tanaman pada setiap minggunya jika dibandingkan dengan perlakuan kontrol dan perlakuan menggunakan fungisida.Perlakuan campuran $P$. fluorescens dan $P$. polymixa hanya meningkatkan tinggi tanaman pada minggu ke-7 dan tidak berbeda nyata dengan perlakuan kontrol dan fungisida pada minggu ke-5, minggu ke -6 dan minggu ke-8.Pengaruh terhadap tinggi tanaman disebabkan karena P. polymixa memiliki kemampuan PGPR (Plant Growt Promoting Rhizobacteri) yang mampu meningkatkan pertumbuhan dengan cara menghasilkan auksin yaitu hormon yang berfungsi untuk memanjangkan sel dan sitokinin, serta memfiksasi nitrogen juga dapat menghasilkan senyawa yang menghambat pembentukan etilen yang berfungsi agar tanaman tidak cepat mati (Timmusk, 2003).
Pengaruh terhadap hasil produksi membuktikan bahwa $P$. fluorescens dan $P$. polymixa dapat meningkatkan hasil produksi. Mila (2012) melaporkan bahwa bakteri dari genus Pseudomonas, Azotobacter, Bacillus dan Seratia, diidentifikasi sebagai PGPR penghasil fitohormon yang mampu meningkatkan pertumbuhan dan hasil tanaman dalam jumlah yang besar khususnya IAA dan ACC deaminase, untuk merangsang pertumbuhan tanaman, memfiksasi nitrogen dan meningkatkan ketersediaan hara P dan hara lainnya (Rao, 1994). Fitohormon adalah senyawa organik bukan hara yang dihasilkan oleh tanaman yang dalam konsentrasi tertentu dapat mendukung atau menghambat pembelahan sel serta berperan dalam pertumbuhan dan perkembangan tanaman (Abidin, 1986).

Pada hasil penelitian ini perlakuan bakteri campuran $P$. polymixa dan $P$. fluorescens tidak berpengaruh terhadap intensitas penyakit hawar upih, tinggi tanaman dan hasil produksi, karena kedua bakteri tersebut memiliki sifat antagonis. Banyak laporan dari hasil penelitian yang menyatakan bahwa kombinasi bakteri antagonis dapat meningkatkan ketahanan terhadap serangan patogen dan memacu pertumbuhan tanaman. Fukui et al (1999) melaporkan penggunaan bakteri campuran tidak lebih unggul dari pada penggunaan bakteri tunggal, karena akan terjadi perebutan karbon antara bakteri didalam tanaman, sedangkan bakteri tunggal akan lebih maksimal dalam menggunakan sumber karbon karena jumlahnya terbatas. 
Aprilia et al (2012) melaporkan bahwa kemampuan antagonis Paenibacillus polymixa lebih tinggi bila dibandingkan dengan kemampuan antagonis Pseudomonas fluorescens dalam pengendalian penyakit karat putih pada krisan, nilai rataan severitas Paenibacillus polymixa adalah $26,79 \%$ dan nilai rataan severitas Pseudomonas fluorescens adalah $32,54 \%$.

\section{KESIMPULAN}

Berdasarkan hasil penelitian yang telah dilakukan, maka disimpulkan bahwa :Aplikasi bakteri P. fluorescens dan P. polymixa tidak mampu menurunkan intensitas penyakit hawar upih. Aplikasi bakteri $P$. fluorescens dan $P$. polymixa dapat menambah tinggi tanaman dan hasil produksi.

\section{DAFTAR PUSTAKA}

Aprilia N. Rares., Emmy Senewe., Guntur S.J Manengkey., Max M. Ratulangi. 2012. Efektivitas Mikroorganisme Antagonis Terhadap Penyakit Karat Putih Pada Tanaman Krisan (Chrysanthemum morifolium Ramat) Di Kota Tomohon. Program Studi Agroekoteknologi, Jurusan Hama \& Penyakit Fakultas Pertanian,Universitas Sam Ratulangi.

BPS Lampung. 2012. Produksi Jagung di Lampung. Badan Pusat Statistika Lampung. Diakses tanggal 20 september 2017.

De Meyer G, Hofte M. 1997. Salicylic acid produced by the rhizobacterium Pseudomonas aeruginosa 7NSK2 induces resistance to leaf infection by Botrytis cinerea on bean. Phytopathology 87(2):588-593.
Fukui, R., H, Fukui., A, M, Alvarez. 1999. Comparisons Of Single Versus Multiple Bacterial Species On Biological Control Of Anthurium Blight. Phitopathologi vol 89. 5: 366-372.

Haggag WM, Mohamed HALA. 2007. Biotechnological Aspects Of Microorganisms Used In Plant Biological Control. Word J Agric Sci.3(6):771-776.

James, W. C. 1971. An Illustrated Series Of Assessment Keys For Plant Diseases, Their Preparation And Usage. Can. Plant Dis. Surv. 51(2): 39-65.

Mila, N.R. 2012. Efek Fitohormon PGPR Terhadap PertumbuhanTanaman Jagung (Zea mays). CEFARS : Jurnal Agribisnis dan Pengembangan Wilayah. 3(2).

Nawangsih, A.A. 2006. Seleksi dan Karakterisasi Bakteri Biokontrol Untuk Mengendalikan Penyakit Layu Bakteri (Ralstonia solanacearum) pada tomat. [Disertasi]. Sekolah Pascasarjana, Institut Pertanian Bogor, Bogor.

Prasetyo G. 2017. Efektivitas Pseudomonas fluorescens dan Paenibacillus polymyxa Terhadap Keparahan Penyakit Karat Dan Hawar Daun SertabPertumbuhan Tanaman Jagung Manis (Zea mays Var. Saccharata).Jurnal Agrotek Tropika. 5(2): 102-108.

Rao, N. S. Subba . 1994. Mikroorganisme Tanah dan Pertumbuhan Tanaman Jakarta : Universitas Indonesia. 
Soenartiningsih, 2015. Cendawan Tular Tanah (Rhizoctonia solani) Penyebab PenyakitBusuk Pelepah pada Tanaman Jagung dan Sorgum dengan Komponen Pengendaliannya. Balai Penelitian Tanaman Serealia. Maros, Sulawesi Selatan.

Sheela, T. dan Usharani. 2013. Colonization Of Exopolysaccharide Producing Paenibacillus polymyxa On Maize ( Zea mays L.) Roots For Enhancing Resistance Against Root Rot Disease. Department Of Microbiology Faculty Of Science Annamalai University, Chidambaram,Cuddalore District Tamil Nadu.

Timmusk, S. 2003 Mechanishem Of Action Of The Plant Growth Promoting Bacterium Paenibacillus polymixa. Acta universitas tisupsaliensis. 